\title{
An update on recent colony losses in Scotland from a sample survey covering 2006-2008
}

\author{
Alison Gray ${ }^{1 *}$, Magnus Peterson ${ }^{1}$ and Alan Teale ${ }^{2}$ \\ ${ }^{1}$ Department of Mathematics and Statistics, University of Strathclyde, Livingstone Tower, 26 Richmond Street, Glasgow, G1 1XH, UK. \\ ${ }^{2}$ Scottish Beekeepers' Association, 8, Mayfield Road, Inverness, IV2 4AE, UK.
}

*Corresponding author: Email: a.j.gray@strath.ac.uk

Keywords: honey bees, Scottish beekeeping, stratified probability sample, Varroa destructor, colony losses

Peterson et al. (2009) reported figures on honey bee colony losses from a postal survey of beekeepers in Scotland carried out in early summer 2006 on behalf of the Executive of the Scottish Beekeepers' Association (SBA). We now provide updated figures on Scottish colony losses and on the reasons for these losses, from a repeat survey in late spring 2008 and covering the period April 2006 to April 2008.

The two surveys covered similar and varied topics, although experience of colony losses and the extent and impact of Varroa destructor (Anderson and Trueman, 2000) were of particular interest. A modified questionnaire was used in the 2008 survey, more detailed information on colony losses sought, and new questions included about migratory beekeeping, and concerns of beekeepers regarding environmental factors. The design of the two surveys was also different.

The target population was the SBA members resident in Scotland, numbering just over 1,000 . The 2008 survey selected a stratified random probability sample, to try to ensure adequate representation of all areas of Scotland. Questionnaires were posted by the SBA Membership Convenor to the 119 randomly selected participants, including nine people from the Hebrides, Orkney and Shetland (outlying areas not covered in the 2006 survey).

Despite careful survey planning and execution, the response rate was just over $40 \%$ (50 respondents out of 119 , 44 of whom were active beekeepers), so the results may suffer from non-response bias. Whilst the sample is small, at the end of the survey period in April 2008 , the median number of colonies kept was four (and the largest was 50), compared to a median of eight colonies in the 2006 survey, and the authors believe that the 2008 profile of size of beekeeping enterprises is much more typical of SBA members than in 2006.

Table 1 summarises overall losses reported for the different periods covered by this survey, for Scotland as a whole and for the main SBA areas (Aberdeen, East, North and West). Unfortunately only one beekeeper from the Aberdeen area responded, and provided no useful information on losses. Responses from the Outer Hebrides and Shetland have been included here with those from the North. A respondent from the Inner Hebrides was included in the West area. There were no participants from Orkney.

About $80 \%$ of respondents reported losses. The number of colonies kept by respondents in September 2007 was 365, and 294 in April 2008 , an over-all decline of $19.5 \%$, the same decline as over the whole survey period (April 2006 to April 2008). This compares to a $30.4 \%$ decline from the end of October 2007 to the end of March 2008 from a survey of colony losses in England (Aston, 2010).

The total number of colonies lost during winter 2006-7 was 70 out of 399 being kept in September 2006, an average winter loss rate of about $18 \%$, whereas in winter 2007-8 79 were lost out of 365 kept in September 2007, an average loss rate of about $22 \%$. Summer losses are more difficult to quantify, because of opportunities to create new colonies, as well as the risk of losing existing ones. However, during the summer of $2006,4.9 \%$ of colonies kept at the start of the season were lost, compared to $9.4 \%$ during the summer of 2007.

Table 1 suggests that winter losses may be higher in the East and West areas, covering the parts of Scotland where $V$. destructor has been established longest (4 (36\%) of respondents from the East and $4(19 \%)$ from the West have had the mite for 5 years or more), compared to the North. However these differences are not statistically significant ( $p$-values for a chi-squared test of lost and surviving colonies versus area are respectively 0.791 and 0.530 for the two winter periods, so may well be due to chance fluctuations). As expected, winter loss rates are higher than summer ones.

Clearly percentage losses experienced by individuals are much more variable than for whole areas. Within any one area, most respondents experienced a low loss rate, but a few experienced high and sometimes devastating losses. Extremely low or extremely high percentage loss rates were confined to smaller enterprises, as judged 
Table 1. Rates of colony losses over two years, and percentage losses attributed to specific causes, over-all and by area. *One respondent from the East area failed to give details for losses in summer 2006 and winter 2006-2007. Other causes reported: mismanagement: 2 lost colonies by 1 respondent; Nosema disease: 5 and 1 colonies by 2 respondents; theft: 1 colony, 1 respondent; weak colonies in poor weather: 8 colonies among 6 respondents with a variety of details; "Internal collapse of hive": 1 colony, 1 respondent; hives overturned by cattle: 4 colonies, 1 respondent; widespread collapse winter 2006-7, may be Nosema or V. destructor. 9 colonies, 1 respondent.

a. Rates of loss per season, total losses (in round brackets) and number of colonies kept at the start of the season (in square brackets) respectively within each cell.

\begin{tabular}{|l|c|r|r|r|r|r|}
\hline \multicolumn{1}{|c|}{ Area } & $\begin{array}{c}\text { No. of } \\
\text { respondents }\end{array}$ & $\begin{array}{c}\text { Proportion } \\
\text { (and no.) } \\
\text { reporting } \\
\text { losses }\end{array}$ & $\begin{array}{c}\text { Summer 2006 } \\
\text { (May 2006- } \\
\text { Sept 2006) }\end{array}$ & $\begin{array}{c}\text { Winter 2006-07 } \\
\text { (Oct 2006- } \\
\text { April 2007) }\end{array}$ & $\begin{array}{c}\text { Summer 2007 } \\
\text { (May 2007- } \\
\text { Sept 2007) }\end{array}$ & $\begin{array}{c}\text { Winter 2007-08 } \\
\text { (Oct 2007- } \\
\text { April 2008) }\end{array}$ \\
\hline Over-all & 44 & $79.6(35)$ & $4.9(18)[365]$ & $17.5(70)[399]$ & $9.4(32)[340]$ & $21.6(79)[365]$ \\
\hline Aberdeen 0 & & - & & - & - & \\
\hline East & 11 & $72.7 *(8)$ & $12.5^{*}(7)[56]$ & $19.7 *(12)[61]$ & $0.0(0)[49]$ & $25.9(15)[58]$ \\
\hline North & 11 & $81.8(9)$ & $8.1(7)[86]$ & $15.5(13)[84]$ & $15.7(14)[89]$ & $18.1(15)[83]$ \\
\hline West & 21 & $85.7(18)$ & $1.8(4)[218]$ & $18.1(45)[249]$ & $9.1(18)[197]$ & $22.4(49)[219]$ \\
\hline Unspecified & 1 & $0.0(0)$ & $0.0(0)[5]$ & $0.0(0)[5]$ & $0.0(0)[5]$ & $0.0(0)[5]$ \\
\hline
\end{tabular}

b. Total losses and \% losses attributed to specific causes (actual losses in brackets).

\begin{tabular}{|l|c|r|r|r|r|r|r|}
\hline \multicolumn{1}{|c|}{ Area } & $\begin{array}{c}\text { Total } \\
\text { losses }\end{array}$ & Starvation & Queenlessness & \multicolumn{1}{c|}{$\begin{array}{c}\text { V. } \\
\text { destructor }\end{array}$} & $\begin{array}{c}\text { "Mary } \\
\text { Celeste" }\end{array}$ & $\begin{array}{c}\text { Diet } \\
\text { change }\end{array}$ & Vandalism \\
\hline Over-all & 199 & $13.6(27)$ & $17.1(34)$ & $11.6(23)$ & $14.1(28)$ & 0.0 & $3.0(6)$ \\
\hline East & 34 & $14.7(5)$ & $17.6(6)$ & $5.9(2)$ & $14.7(5)$ & 00 & 0.0 \\
\hline North & 49 & $36.7(18)$ & $20.4(10)$ & $2.0(1)$ & $4.1(2)$ & 0.0 & $2.0(1)$ \\
\hline West & 116 & $3.4(4)$ & $15.5(18)$ & $17.2(20)$ & $18.1(21)$ & 0.0 & $4.3(5)$ \\
\hline
\end{tabular}

by number of colonies kept at the beginning of the period under investigation, and may be attributed to random fluctuations among small samples.

Respondents were asked to attribute causes to losses, as far as possible. Possible reasons suggested in the questionnaire were: starvation, queenlessness, V. destructor, the "Mary Celeste" (MC) type loss; changes in diet; and vandalism, with respondents able to suggest other possible causes not listed, as is standard practice in questionnaire design. Table 1 also shows percentages of losses attributed to these causes. The leading assigned cause of loss is queenlessness. The MC type loss, used to describe the situation in which an apparently flourishing hive is suddenly found abandoned with still ample stores in the combs, which shows some similarities with the symptoms of "Colony Collapse Disorder" (CCD: van Engelsdorp et al., 2009), ranks second, above starvation. In the North, the rather high percentage loss due to starvation was heavily influenced by the many colonies lost by one larger scale beekeeper in the inclement summer of 2007. V. destructor is also cited as an important cause of loss; only one respondent (9\%) from the East area claimed not yet to have found the mite in their bees, compared to five (24\%) from the West and four (36\%) from the North. This sample includes beekeepers from very remote northern locations, so it does appear that some more remote parts of Scotland are still clear of $V$. destructor. Change of diet was not cited at all as a cause of loss. About $40 \%$ of losses have not been assigned to any of the causes suggested, but see Table 1 for other causes cited.

In 2006, information was sought on unexplained losses and numbers of such losses of MC type, whereas in 2008 it was thought more useful to ask about all losses, not just those thought to be unexplained. The overall proportions of unexplained losses reported in the 2006 survey were, for winter losses, $4.7 \%$ in $2004-5$ and $7.3 \%$ in 2005-6, and in summer 2005, 2.2\%. The 2008 survey figures most nearly corresponding to these are, for all losses, $18 \%$ for winter 2006-7, $22 \%$ for winter $2007-8,4.9 \%$ for summer 2006 and $9.4 \%$ for summer 2007. The overall proportions of unexplained losses reported as MC type in the 2006 survey were high (about $45 \%$ for the first winter, about $42 \%$ for the second winter, and about $58 \%$ for summer 2005), but these cannot be compared directly to the 2008 figures.

Full survey results will be made available at the SBA Website (at http://www.scottishbeekeepers.org.uk/ ). 


\section{References}

ANDERSON, D L; TRUEMAN, J W H (2000) Varroa jacobsoni (Acari: Varroidae) is more than one species. Experimental and Applied Acarology 24: 165-189.

ASTON, D (2010) Honey bee winter loss survey for England 2007-8. Journal of Apicultural Research 49(1):
VAN ENGELSDORP, D; EVANS, J D; SAEGERMAN, C; MULLIN, C; HAUBRUGE, E; NGUYEN, B K; FRAZIER, M; FRAZIER, J; COXFOSTER, D; CHEN, Y; UNDERWOOD, R M; TARPY, D R; PETTIS, J S (2009) Colony Collapse Disorder: a descriptive study. PloS ONE 4: e6481.

PETERSON, M; GRAY, A; TEALE, A (2009) Colony losses in Scotland in 2004-2006 from a sample survey. Journal of Apicultural Research 48 (2): 145-146. DOI: 10.3896/IBRA.1.48.2.11 